\title{
The COVID-19 Pandemic and Human Dignity: the Case of Migrant Labourers in India
}

\author{
Anoop C. Choolayil ${ }^{1}$ [ $\cdot$ Laxmi Putran ${ }^{1}$
}

Accepted: 21 June 2021 / Published online: 13 July 2021

(c) The Author(s), under exclusive licence to Springer Nature Switzerland AG 2021

\begin{abstract}
Being one of the badly affected nations by the novel coronavirus, the Indian government had rolled out a set of strategies to contain the transmission. While measures like the lockdown inflicted significant damage on many sections of society, the interstate migrant labourers' plight across India was nothing less than disastrous. While the privileged sections of the society could afford the strict restrictions laid down by the state, the migrant labourers stuck in different parts of the country found themselves to be second class citizens. This research is an ethical discourse on the human dignity of migrant labourers in a welfare state during the pandemic context. Data gathered from reports on the subject matter in media licensed by the state were analysed under the theoretical lens of violation of human dignity. The outcome of the research involves a critical appraisal of the human dignity of the marginalised in a so-called modern welfare state.
\end{abstract}

Keywords Welfare state $\cdot$ Human dignity $\cdot$ Intersectionality $\cdot$ Privilege $\cdot$ Migrant labourers $\cdot$ COVID-19

\section{Background of the Study}

COVID-19 has been one of the most deadly pandemics in the era of modern virology. The absence of pathogenspecific treatment has made the world rely on preventive strategies, paired with symptomatic treatment for containing the virus. The pandemic has disrupted the global economy and has adversely affected social lives to a great extent. The impact of the pandemic on the social and economic systems has made it a matter of national priority for the world's nations. Hence, governance has become a key element in the management of the pandemic situation. The quick transmission rate and the potential damage of the virus made the world's nations roll out preventive measures like lockdown of public spaces and travel bans. The battle against COVID-19, hence, is not just a battle between modern medicine and a pathogen; rather, a fight between the state and the pathogen. The implications of this 'state versus pathogen' scenario on the lives of the common

Anoop C. Choolayil

anoopcchoolayil@gmail.com

Laxmi Putran

laxmi@cukerala.ac.in

1 Department of Social Work, Central University of Kerala, Kasaragod, India people involve a debate on the 'ethics of the state-initiated measures'. While the state necessarily makes decisions on the premise of the 'welfare of the citizens', its universality is a matter of concern. Citizens of a nation fall under multiple categories that may be overlapping implying intersectionality. For instance, one can be a citizen of India, be poor and be a migrant labourer, all at the same time. The measures taken by the state in the purview of the welfare of the citizens need not always address the disadvantaged citizens.

The government of India, also known as the Indian Union, announced a nationwide lockdown on $24 \mathrm{March}$ 2020, imposing travel bans and restrictions on gathering in public spaces to contain the spread of COVID19 pandemic. However, the state-formulated strategy of 'lockdown' did not take into account many of the disadvantaged citizens, migrant labourers being one of the most affected groups. Migrant labourers contribute to the economic development of India; especially to infrastructure development. Major cities across India rely on migrant labourers for infrastructure-related labour and other unskilled jobs, often involving exploitation of these people. The pandemic control measures left migrant labourers across India without any work and income. To aggravate the situation, the migrants could not travel back to their hometowns due to the travel ban. This article critically appraises how migrant labourers were affected by the COVID-19 contain- 
ment measures of the state and the response of the state to the same. The enquiry relies on reports from state-licensed media houses on the subject matter. The research involves an ethical discourse on 'human dignity in a welfare state' followed by a critical analysis of content generated by media on the 'state of migrant labourers' during the pandemic.

\section{Human Dignity and Human Rights in a Welfare State: an Analysis of the Indian Context}

The concept of human dignity as it stands today has evolved mainly from the 'Kantian deontology'. According to the deontological ethical position, human beings are 'ends in themselves' and hence have a moral dimension to them, making them possess inherent dignity. The assumption is strictly in contradiction to the idea that dignity is associated with utility. Instead, the idea is that humanity in itself has dignity (Sensen, 2016). Modern-day societies have developed the concept of human dignity in and around the Kantian deontological position. The international mandates reiterate that human dignity is a characteristic common to all human beings equally (Kotzmann \& Seery, 2017).

Article 1 of the United Nations Universal Declaration of Human Rights (1948) postulates that 'All human beings are born free and equal in dignity and rights'. Human dignity, thus, is a fundamental assumption in the modern-day human rights concept. A person could be stripped off from his/her state of dignity mainly in four ways viz. humiliation, instrumentalisation, degradation and dehumanisation (Kaufmann et al., 2011). The state is the social institution deemed to protect human dignity. Article 22 of the United Nations Universal Declaration of Human Rights (1948) calls upon the member states to ensure social security along with economic, social and cultural rights in order to ensure human dignity. It is from the concept of human dignity that human rights originate. Thus, the concept of human dignity is an underlying principle of a welfare state. By virtue of its responsibility to protect human dignity, every welfare state should ensure that unemployment or disability does not deprive people of the means of existence, human rights of every citizen are intact, a functioning, productive and sustainable economy is in place, assistance is provided to people who cannot help themselves and existential risks including fear are eliminated (Steigleder, 2014). Welfare states respond to the demand for human dignity by establishing 'fundamental rights' in accordance with their resources as called upon by Article 22 of the United Nations Universal Declaration of Human Rights.

The Indian Union is a welfare state and has human dignity as one of the cornerstones of its constitution. The idea of governance in India is guided by the notion of a welfare state as enshrined in Article 38 of the Indian constitution that seeks to establish a just social order in social, economic and political terms in the welfare state (Bakshi \& Kashyap, 1982). The social order in the welfare state resonates with the idea of social justice, which is rights-centred, aiming at improving the lives of all the citizens, especially the marginalised. The fundamental rights function as the ground for ensuring social justice. The fundamental rights in the Indian constitution aim at the protection of the human dignity of its citizens. The constitution guarantees its citizens' dignity through the seven fundamental rights viz. the right to equality, right to freedom, right against exploitation, right to freedom of religion, cultural and educational rights, right to property and right to constitutional remedies (Austin, 1999).

The implementation of the idea of a welfare state in India is determined mainly by the quasi-federal nature state. The Directive Principles of State Policy in the Indian Constitution, where the Constitution calls for the pursuit of a welfare state, are instrumental in the governance but not justiciable. These principles guide the law-making process in the state. However, law-making in India is largely shaped by the quasi-federal governance system. Governmental powers are divided among the central and state governments through the system of three lists viz. the union list, the state list and the concurrent list, the first two being exclusive to the central and state governments, respectively, and the third one shared among the two (Bakshi \& Kashyap, 1982). Welfare of labourers is an item in the concurrent list and hence the central and provincial governments are equally responsible for the same.

A welfare state that is guided by the idea of social justice ensures the implementation of constitutional provisions through legislation. In order to ensure the constitutional rights of the interstate migrant labourers, The Inter-State Migrant Workmen Act (1979) was introduced by the central government. The act mandates welfare provisions for interstate migrant labourers like equal wages, displacement allowance, governmental supervision of working conditions and legal assistance. From a theoretical point of view, the act resonates with the commitment of the state towards the welfare of migrant labourers and it has significantly contributed to the betterment of their employment prospects. On the other hand, the discrimination of migrant labourers has not significantly reduced in many parts of the country. It ranges from economic (Ashok \& Thomas, 2014a, b; Kapoor, 1987; Reddy \& Olsen, 2012; Srivastava, 2019) to social (Banerjee \& Knight, 1985; Ito, 2009).

\section{Migrant Labourers in India: an Overview}

With an increasing divide between the poor and the rich in the progressively liberal economy in India, the poor and the marginalised are forced to migrate to urban areas in search of 
jobs. The movement of the people from the villages to urban locations is not just the outcome of poverty but that of the intersectionality of poverty and casteism, among many other factors. The migration of unskilled labourers in India can be both intra-state and inter-state. According to the 2011 census, there are 307 million people in India who had migrated from their place of birth out of which 41 million (13\%) were interstate migrants. Among these 307 million migrants, 140 million move in search of work. The migrants who move from one state to another state could be either skilled or unskilled. Migrant labourers are often employed in the informal segment that requires unskilled or semi-skilled works, typically involving high-risk, low-income jobs (DDU-GKY Ministry of Rural Development, 2018). There are at least 100 million low waged migrant labourers in the workforce of the Indian economy (Shah \& Lerche, 2020). The unskilled migrant labourers constitute a group that is often discriminated against and marginalised. Among these unskilled migrant labourers, 56 million comprise interstate migrant labourers (Census, 2011), the majority of whom work in the unorganised sector for daily livelihood. In many cases, these workers would not possess even a valid identity card given the nature of their work (Varma, 2020).

\section{Interstate Migrant Labourers and Intersectionality}

The idea of intersectionality involves how different discriminations are interlinked and affect each other. It investigates how power relations can influence social relations and personal experiences. Intersectionality is a framework that examines social and political life as a product of multiple factors. An intersectional view of social inequality would suggest the intertwining nature of social divisions contributing to the situation (Collins \& Bilge, 2016). An intersectional worldview of the interstate migrant worker population in the unorganised sector would throw light to multiple axes that contribute to each other. Caste, class, ethnicity and many other aspects contribute to the plight of the migrant labour population, both in the native states and the host states.

Poverty is one of the root factors contributing to interstate migration in India. Poor people, mostly hailing from rural areas across India, migrate to states with better HDI and economic prosperity in search of a fortune. The poverty of these people, however, is not an independent phenomenon. Interstate migrant labourers in India constitute a group that faces multiple overlapping disadvantages. The people who are considered the lowest in the caste hierarchy are found to be engaging in the hardest work under poor conditions as migrant labourers. These labourers hail from the states with the lowest human development indices that are notorious for the wealth extraction by upper castes leaving the lower caste people with almost no wealth (Shah \& Lerche, 2020).
The intersectional nature of interstate labour migration in India is evident from how the caste system induces poverty which in turn leads to migration to other states. Lower caste people are often assigned to low-paid dead-end jobs and are subject to discrimination at the workplace (Banerjee \& Knight, 1985; Das \& Dutta, 2007; Madheswaran \& Attewell, 2007). Interestingly, the plight does not end in the native states. The migrant labourers often enter the labour market through brokerage systems. The labour brokers in the host states often exploit the labourers by employing them for lower wages (Picherit, 2019). The people who experience discrimination at the levels of class and caste in their hometowns when migrated to a new state experiences even more discrimination based on language and ethnicity. In addition to the poverty and casterelated discriminations in the native state, the migrant labourers experience discrimination from the people of the 'receiving states' in ethnicity and linguistic terms, among others. This double burden of discrimination in the native state and the 'receiving state' is a severe dignity violation. The alienation from homeland and relatives paired with poverty and discrimination makes the interstate migrant labourers one of the most vulnerable sections of the population. It is hence evident that interstate migrant labourers constitute a marginalised section of the society and undergo multiple level discriminations in a so-called welfare state.

\section{The Downside of Being an Interstate Migrant Labourer in India}

The discrimination that the migrant labourers undergo worsens their socio-economic conditions. The problems of a migrant labourer begin with housing and extend to risk to life. Migrant labourers live under unhygienic, packed housing infrastructures to minimise the cost of living. In an effort to cut the cost of living in the 'receiving state' migrant labourers often end up living in unsanitary conditions, following a poor diet, compromising on personal hygiene and thus putting themselves in hazardous living conditions (Ashok \& Thomas, 2014a, b; De Haan, 1997; Zabeer et al., 2019). Besides the difficulties in living arrangements, migrant labourers are exposed to dangerous work conditions. Interstate migrant labourers are often employed in hazardous work environments like construction sites that pose the risk of accidents, falls, and machinery-induced injuries (Jane, 2016). Also, interstate migrant labourers are exploited with meagre pay and extended working hours (Agarwal \& Raj, 2020). Often, migrant labourers have no role in decisionmaking regarding the work domains. Contractors from the 'receiving state' own the decision-making process. This is because migrant labourers are unfamiliar with the sociocultural fabric of the 'receiving state' and also since they are recruited through private firms and individuals due to the absence of a state-imposed system. 
Life as a migrant labourer in India involves one that of discrimination and exploitation. Besides the discrimination in the native place based on class and caste, they often undergo discrimination and exploitation in the 'receiving state'. This state of life as a discriminated and exploited human person raises the question of human dignity. The migrant labourers are entitled to be citizens with dignity, as per the international conventions and the Indian constitution but often are deprived of this dignity they deserve. The pandemic situation furthered this crisis, and the violation of human dignity of migrant labourers in the welfare state of India is discussed in the following section.

\section{The Impact of the COVID-19 Pandemic on Interstate Migrant Labourers}

The COVID-19 pandemic induced an unprecedented difficult situation, and the population, in general, experienced hardships on economic, social and psychological fronts. The interstate migrant labourers, as a vulnerable group, faced unprecedented hardships on multiple fronts, including material, psycho-social and socio-political.

Material Impact The most basic effect of the pandemic on the migrant labourers was on the economic front. The pandemic struck the labour market, and unskilled labourers with no proper job security soon found themselves to be jobless and consequently devoid of economic resources to survive. The pandemic control measures like the lockdown made the migrant labourers lose their already uncertain employment prospects (Guha et al., 2020; Khanna, 2020). The pandemic not only induced a no-income situation for the migrant labourers in India but had an impact even on the basic needs (Singh, 2020). The pandemic induced economic uncertainty, in turn, paved the way for psycho-social distress among migrant labourers.

Psycho-social Impact The migrant labourers were distressed by the uncertainty of the duration of the lockdown, inability to travel and meet their families, fear of abandonment by the employers, insecure job prospects, etc. (Chander et al., 2020; Kumar et al., 2020). This, paired with the fear of social exclusion, aggravated the distress of migrant labourers. Social exclusion adversely affected the mental health of migrant labourers as they are vulnerable to loss of social status and discrimination. The state-promulgated measures like mandatory isolations and quarantine took a toll on the mental health of the migrant labourers (Choudhari, 2020).

The Socio-political Dimension of the Pandemic Induced Hardships of Migrant Labourers The hardships faced by the migrant labourers during the pandemic shows how the social system precariously contributed to the plight of the migrant labourers. The state mechanisms' inability to ensure the welfare of migrant labourers as a group during an adverse event showed the shallow nature of the social security measures on offer for the migrant labourers. Labour is a subject in the concurrent list of the Indian constitution, which implies that the state and the central governments are equally responsible for initiating welfare measures in this regard. However, the absence of a direct grievance redressal mechanism for migrant labourers explains the inefficacy of the state mechanism in this regard. The suo moto interference of the Supreme Court of India, on cognisance of the violation of fundamental rights of migrant labourers and directing the state to address the immediate needs of the migrant labourers strengthen the argument that the state had not been addressing the scenario in an efficient and desirable manner (Chander et al., 2020; Rajagopal, 2020).

While the policies and legislation in black and white revolve around the idea of ensuring the welfare of migrant labourers, the practical situation is far from ideal. It is disappointing that the system that exploits the migrant labourers for economic development does not pay them the worth they deserve as human beings. There is a constant interplay of state and societal factors in the plight of the migrant labourers which was brought to light vividly during the pandemic. While some of the actions of the state had been least considerate to the migrant labourers, contributing to their plight (BBC, 2020; Aljazeera, 2020; Gupta et al., 2020; Pandey, 2020; Chaturvedi, 2020; First Post, 2020; Babu \& Sahay, 2020; Kulkarni, 2020), it was the state's inefficacy in handling the situation and inaction that lead to mounting difficulty for them in some instances (Lalwani, 2020; Ameen, 2020; The Wire, 2020; The Federal, 2020; News 18, 2020; Kulkarni, 2020). Societal attitudes had also been adding to the plight of migrant labourers through negative outlooks and unfavourable responses (The New Indian Express, 2020; Tomlinson \& Chaurasia, 2020).

The interplay of state and societal factors made migrant labourers undergo severe violations of human dignity during the pandemic. While it could be argued that migrant labourers undergoing violations of human dignity are individual cases lacking a collective nature, it could be seen that individual cases incur a collective aspect to this case. The Central Government of India's official statement in Parliament that it has no data at all on the death and job loss of migrant labourers during the pandemic (Nath, 2020) asserts the fact that the instances of violation of human dignity of migrant labourers were not isolated events, but the outcome of a complacent system and complimentary society that pays no serious attention to the cause of the migrant labourers. The seemingly isolated cases of the violations of human dignity occurring in the background of this underwhelming administrative system, collectively contributed to the general state of 'violation of human dignity' faced by the migrant labourers 
during the pandemic. The article discusses the pandemicinduced violations of the dignity of the interstate migration population in India through an analysis of state-licensed media reports.

\section{Method and Materials}

This study is a qualitative enquiry on the case of violation of the dignity of unskilled interstate migrant labourers in India during the pandemic. The case has been researched from the vantage point of 'human dignity' (Sensen, 2016) within the theoretical framework of 'violation of human dignity' (Kaufmann et al., 2011). The research employs a narrative method, constructing a narration on the status of the dignity of migrant labourers during the pandemic through events reported in state-licensed media. The data for the study had been gathered from media reports in the period from March 24 (the day of announcement of lockdown in India) to May 24, 2020 as interstate migrant labourers were either stranded in host states or struggling their way back to the home states during this period. The cases of violations of the dignity of the migrant labourers during this period in India were located using a web search with the combinations of the keywords 'migrants', 'migrant labourers', 'pandemic', 'human dignity', 'human rights', 'discrimination' and 'India'. The results pertaining to unskilled interstate migrant labourers that were media reports from state-licensed media houses were evaluated within the framework of "violations of human dignity', and the relevant results were enlisted for further analysis (Table 1). At this stage, reports by nonlicensed media houses were eliminated and hundred percent inter-coder agreement was reached regarding the enumeration of the dignity-violation in the report. It was also made sure that only the reports enumerating factual events were selected and those which were opinions or statements were eliminated, to ensure objectivity. The selected reports fell under three major categories viz.

a. Violations due to perpetuation by state/state mechanism: Reports in this category include events where a state government or its machinery, mainly bureaucracy, committed an action that violated the dignity of the migrant labourers.

b. Violations due to the inefficacy of state/state mechanism: Reports in this category include cases where the dignity of migrant labourers was compromised due to the inefficiency of the state, mostly inability to initiate necessary actions to avoid adverse actions.

c. Violations due to perceptions of the society: Reports in this category include actions or perceptions of people in general that has contributed to the violation of the dignity of migrant labourers.

The three categories of reports were analysed within the framework of violations of human dignity to narrate the case of human dignity of migrant labourers during the pandemic in India. A total of 25 reports were enlisted and the selected reports were analysed thematically in the framework of violation of human dignity involving humiliation, degradation, instrumentalisation and dehumanisation (Kaufmann et al., 2011). The cases presented in the reports were often mutually inclusive, i.e. one form of violation included elements of another form of violation. In such cases, the reports were considered under the forms of violations to which it largely resonated. The thematically coded findings from the reports are presented in the following sections.

\section{The Humiliation of Unskilled Interstate Migrant Labourers During the Pandemic}

Humiliation involves any infliction of insult on pride as an individual or a group. It involves an emotional experience following a forced or conscious degradation of the social status (Burton, 2014). Humiliation is an objective reality as well as a subjective experience to the victim. Violation of human dignity through humiliation can be inflicted upon an individual or on a group (Kaufmann, et al., 2011). Kaufmann (2011) suggests that a group could be humiliated in three ways viz. 'direct group humiliation', 'symbolic humiliation' and 'representative group humiliation'. In the Indian context, the constitution and legislations ensure that minimal direct and symbolic humiliations take place. However, 'representative humiliation' involves humiliating an individual or some individuals in a group which consequently incurs a humiliation on the whole group. This was present during the pandemic in the case of the migrant labourers.

The Indian state declared a lockdown on 24 March 2020 which lead to job loss and subsequent loss of livelihood leaving the migrant labourers stranded in host states. The travel ban enacted with the lockdown forced many povertystricken migrant labourers to travel on foot to reach home states (Pandey, 2020). After an excruciating trek across states to reach the home town, the migrant labourers faced a humiliating situation. The bureaucrats in the administrative system of some states considered the interstate migrant labourers as potential virus carriers and the method employed by the officials in the state of Uttar Pradesh was humiliating and violated the human dignity of the migrant labourers as a group. The officials instead of employing any scientific measures sprayed chemical solutions on the migrant labourers (BBC, 2020; Aljazeera, 2020; Gupta et al., 2020). This 
Table 1 Summary of media reports used in the content analysis

\begin{tabular}{|c|c|c|c|c|c|}
\hline News portal & $\begin{array}{l}\text { Number of reports } \\
\text { used (with code } \\
\text { names) }\end{array}$ & $\begin{array}{l}\text { Publishing date of the } \\
\text { reports (March 24-May 30, } \\
\text { 2020) }\end{array}$ & Content of the report & $\begin{array}{l}\text { State-licensed company } \\
\text { name and corporate identi- } \\
\text { fication number (issued by } \\
\text { the Registrar of Companies, } \\
\text { Govt. of India) }\end{array}$ & Reg. no \\
\hline Al Jazeera & $1(\mathrm{R} 1)$ & April 6 & $\begin{array}{l}\text { Perpetuation by state/state } \\
\text { mechanism }\end{array}$ & $\begin{array}{l}\text { Al Jazeera Media Network } \\
\text { Private Limited } \\
\text { U93000D12016Ptc308295 }\end{array}$ & 308,295 \\
\hline $\mathrm{BBC}$ & $1(\mathrm{R} 2)$ & March 31 & $\begin{array}{l}\text { Perpetuation by state/state } \\
\text { mechanism }\end{array}$ & $\begin{array}{l}\text { BBC World Service India } \\
\text { Private Limited } \\
\text { U22300D12007Ftc167784 }\end{array}$ & 167,784 \\
\hline $\mathrm{CNN}$ & 1 (R3) & April 1 & $\begin{array}{l}\text { Perpetuation by state/state } \\
\text { mechanism }\end{array}$ & $\begin{array}{l}\text { Network18 Media \& Invest- } \\
\text { ments Limited } \\
\text { L65910Mh1996Plc280969 }\end{array}$ & 280,969 \\
\hline Deccan Herald & $1(\mathrm{R} 4)$ & May 6 & $\begin{array}{l}\text { Perpetuation by state/state } \\
\text { mechanism }\end{array}$ & $\begin{array}{l}\text { The Printers (Mysore) } \\
\text { Private Limited } \\
\text { U22110Ka1948Ptc000521 }\end{array}$ & 521 \\
\hline Firstpost & 1 (R5) & May 20 and April 6 & $\begin{array}{l}\text { Perpetuation by state/state } \\
\text { mechanism }\end{array}$ & $\begin{array}{l}\text { Network18 Media \& Invest- } \\
\text { ments Limited } \\
\text { L65910Mh1996Plc280969 }\end{array}$ & 280,969 \\
\hline India Today & 3 (R6, R7, R8) & $\begin{array}{l}\text { March 26, April } 8 \text { and May } \\
30\end{array}$ & $\begin{array}{l}\text { Inefficacy of state/state } \\
\text { mechanism }\end{array}$ & $\begin{array}{l}\text { India Today Online Private } \\
\text { Limited } \\
\text { U99999D12000Ptc107733 }\end{array}$ & 107,733 \\
\hline News 18 & 1 (R9) & May 29 & $\begin{array}{l}\text { Inefficacy of state/state } \\
\text { mechanism }\end{array}$ & $\begin{array}{l}\text { Network18 Media \& Invest- } \\
\text { ments Limited } \\
\text { L65910Mh1996Plc280969 }\end{array}$ & 280,969 \\
\hline Newsclick & 1 (R10) & April 17 & $\begin{array}{l}\text { Inefficacy of state/state } \\
\text { mechanism }\end{array}$ & $\begin{array}{l}\text { Newsclick Studio Private } \\
\text { Limited } \\
\text { U22300D12018Ptc328344 }\end{array}$ & 328,344 \\
\hline Outlook & $1(\mathrm{R} 11)$ & May 21 & $\begin{array}{l}\text { Inefficacy of state/state } \\
\text { mechanism }\end{array}$ & $\begin{array}{l}\text { Outlook Publishing (India) } \\
\text { Private Limited } \\
\text { U67120Mh1992Ptc066495 }\end{array}$ & 66,495 \\
\hline The Federal & 1 (R12) & May 23 & $\begin{array}{l}\text { Inefficacy of state/state } \\
\text { mechanism }\end{array}$ & $\begin{array}{l}\text { New Generation Media } \\
\text { Corporation Private } \\
\text { Limited } \\
\text { U22110Tn2006Ptc059092 }\end{array}$ & 59,092 \\
\hline The Hindu & 2 (R13 and R14) & May 8 and May 16 & $\begin{array}{l}\text { Inefficacy of state/state } \\
\text { mechanism } \\
\text { Perpetuation by state/state } \\
\text { mechanism }\end{array}$ & $\begin{array}{l}\text { Kasturi \& Sons Limited } \\
\text { U22110Tn1940Plc001091 }\end{array}$ & 1091 \\
\hline The Hindustan Times & 2 (R15 and R16) & May 5 & $\begin{array}{l}\text { Perpetuation by state/state } \\
\text { mechanism }\end{array}$ & $\begin{array}{l}\text { The Hindustan Times Ltd } \\
\text { U74899D11927Plc000155 }\end{array}$ & 155 \\
\hline The Indian Express & 1 (R17) & May 8 & $\begin{array}{l}\text { Inefficacy of state/state } \\
\text { mechanism }\end{array}$ & $\begin{array}{l}\text { The Indian Express Private } \\
\text { Limited } \\
\text { U22120Mh2003Ptc142983 }\end{array}$ & 142,983 \\
\hline The Print & 2 (R18, R19) & April 2 and May 22 & $\begin{array}{l}\text { Perpetuation by state/state } \\
\text { mechanism }\end{array}$ & $\begin{array}{l}\text { Printline Media Private } \\
\text { Limited } \\
\text { U22130D12016Ptc306028 }\end{array}$ & 306,028 \\
\hline The Quint & $1(\mathrm{R} 20)$ & May 2 & $\begin{array}{l}\text { Inefficacy of state/state } \\
\text { mechanism }\end{array}$ & $\begin{array}{l}\text { Quintillion Media Private } \\
\text { Limited } \\
\text { U74999D12014Ptc270795 }\end{array}$ & 270,795 \\
\hline The Telegraph & $1(\mathrm{R} 21)$ & May 23 & $\begin{array}{l}\text { Inefficacy of state/state } \\
\text { mechanism }\end{array}$ & $\begin{array}{l}\text { Telegraph News Network } \\
\text { Private Limited } \\
\text { U64204Up2011Ptc044109 }\end{array}$ & 44,109 \\
\hline The Times & 1 (R22) & April 8 & Perception by the society & $\begin{array}{l}\text { Bennett Coleman And } \\
\text { Company Limited } \\
\text { U22120Mh1913Plc000391 }\end{array}$ & 391 \\
\hline
\end{tabular}


Table 1 (continued)

\begin{tabular}{|c|c|c|c|c|c|}
\hline News portal & $\begin{array}{l}\text { Number of reports } \\
\text { used (with code } \\
\text { names) }\end{array}$ & $\begin{array}{l}\text { Publishing date of the } \\
\text { reports (March 24-May 30, } \\
\text { 2020) }\end{array}$ & Content of the report & $\begin{array}{l}\text { State-licensed company } \\
\text { name and corporate identi- } \\
\text { fication number (issued by } \\
\text { the Registrar of Companies, } \\
\text { Govt. of India) }\end{array}$ & Reg. no \\
\hline The Week & 1 (R23) & May 17 & Perception by the society & $\begin{array}{l}\text { The Malayala Manorama } \\
\text { Co Ltd } \\
\text { U22121K11889Plc000647 }\end{array}$ & 647 \\
\hline The Wire & 2 (R24 and R25) & April 6 and May 27 & $\begin{array}{l}\text { Perpetuation by state/state } \\
\text { mechanism } \\
\text { Perception by the society }\end{array}$ & $\begin{array}{l}\text { Foundation For Independ- } \\
\text { ent Journalism } \\
\text { U74140D12015Npl285224 }\end{array}$ & 285,224 \\
\hline
\end{tabular}

method was deemed unscientific by the World Health Organisation (Fox, 2020). While none of the expatriated citizens residing overseas had to undergo this unscientific procedure, migrant labourers had to undergo this humiliation indicating a clear-cut case of discrimination and violation of human dignity. While this could be considered as an administrative mistake than the state policy, this random act of 'representative humiliation' portrayed a picture of migrant labourers as unclean pathogen carriers.

The migrant labourers found themselves as the modernday untouchables during the pandemic. During their excruciating trek across states to reach their native states, they were 'social-distanced' by those in the privileged classes to avoid potential transmission. The situation was not any different in their hometowns as there were reports regarding how villagers blocked the migrant labourers from entering their own homes in states like West Bengal, Bihar, Jharkhand, Rajasthan, Chhattisgarh and Uttarakhand (The New Indian Express, 2020; Tomlinson \& Chaurasia, 2020). The system of social distancing unintentionally paved the way for the strengthening of the class divide. The privileged and the elite class could afford the so-called social distancing while migrant labourers and other poor sections of the society found themselves in a disadvantaged position (Chowdhury, 2020; Wankhede, 2020). In some cases, the intersectionality of caste and migrant status were clearcut, as there were instances of Dalit migrant labourers losing jobs and being accused of spreading the virus even by the state mechanisms, as in the case of Uttar Pradesh (Agoramoorthy \& Hsu, 2021; Ganguly, 2020).

The 'representative humiliation' during the pandemic involves a special characteristic in terms of perpetuation. The perpetuation was not the outcome of a deliberate and organised effort but a confluence of intersectional elements. The prejudices and stigmas associated with the group paved the way to the humiliation of migrant labourers during the pandemic; both from the administrative and societal ends. The migrant labourers being citizens and human beings with equal dignity as the other sections of the society, underwent humiliation and hence their dignity as a group had been violated.

\section{Degradation of Unskilled Interstate Migrant Labourers During the Pandemic}

Degradation is an encroachment upon a person's autonomy and infliction of violence on one's emotional experience. Degradation usually involves a person to act against his/ her will and is characterised by a lack of respect for his/her personality (Webster, 2011). Degradation is a common form of violation of dignity in the day-to-day lives of migrant labourers, often manifested in forms of poor independence in decision-making, poor living arrangements offered by contractors, etc. The pandemic precipitated a situation that has escalated the violation of human dignity of migrant labourers in the form of degradation. One of the striking aspects of the degradation during pandemic involves the degradation of migrant labourers as a group. There were reports on how they were restricted from making choices of their own, including travel and living arrangements during the pandemic.

There had been many instances of degradation of migrant labourers as a group. The first among them being the travel arrangements for interstate migrant labourers. Though the state-arranged 'Shramik trains' for migrant labourers, the number of trains were short of the demand, forcing thousands of migrant labourers to travel on feet to their hometowns (India Today, 2020). The migrant labourers found themselves degraded or as second class citizens as the government had no systematic plan in effect for their repatriation and rehabilitation. While the citizens working overseas were systematically repatriated by the state, the migrant labourers from within the Indian Union received less attention. The few trains arranged by the government to repatriate the migrant labourers were running late and short of food and water in many cases; though Indian railways claim otherwise (Lalwani, 2020; Ameen, 2020; The Wire, 2020; The 
Federal, 2020; News 18, 2020). These incidents point to a degradation of migrant labourers as a group.

While the migrant labourers were walking their way back to their villages, among other constraints they faced was a systematised degradation from the law and order maintenance machinery of the states. Reports suggest that migrant labourers were made to stay out of the city roads and even had to bribe to travel on foot (Pandey, 2020). It shows how the state machinery, especially the law and order machinery, that should ensure the dignity of the migrant labourers miserably failed in their duty in at least a few instances. Also, the migrant labourers paid exorbitant fees to travel in packed buses with little to no preventive measures in place (Outlook, 2020).

\section{Instrumentalisation of Unskilled Interstate Migrant Labourers During the Pandemic}

Instrumentalisation involves using people as means to achieve ends, i.e. to treat people as objects to gain something (Kaufmann, 2011). While instrumentalisation is a common form of violation of human dignity against migrant labourers in the free market economies, the pandemic situation paved for even more instrumentalisation. Political and organisational entities took advantage of the plight of the migrant labourers during the pandemic.

The lack of a uniform state-run system to facilitate the transportation of migrant labourers led to political bargains in many states of India. In the state of Uttar Pradesh, for instance, an opposition party offered free buses for transporting migrant labourers to their hometowns. The offer was denied by the state government citing alleged forging of vehicle documents (Chaturvedi, 2020; First Post, 2020). The incident shows how the plight of migrant labourers was put to use by political parties to attain their goal of increased Public Relations Rating. A similar incident was reported in the state of Kerala where one of the opposition parties offered to bear the travelling cost of migrant labourers, but the state government rejected the offer (Babu \& Sahay, 2020). These incidents show how political parties consider migrant labourers as mere instruments. This points to a violation of the dignity of migrant labourers as a group through instrumentalisation.

While choosing to work or not work in a particular place is the choice of an individual guaranteed by the constitution of India, the pandemic period saw one of the organised violations of this freedom ensured by the constitution. A letter by the Karnataka state government dated May 5, 2020, allegedly sought the railways to cancel trains for migrant labourers after reported pressure from the builders' association (Kulkarni, 2020). The move by the state is a clear-cut case of instrumentalisation of migrant labourers for economic reasons. The incident points to the fact that the wealthy in the free market economy lobby with the state mechanism to exploit migrant labourers as instruments to achieve their goals. The choice to travel home was stripped off from the migrant labourers by the very own machinery which was supposed to ensure their dignity. In addition to such established measures, the way employers left the migrant labourers to suffer by not providing any financial assistance for survival during the pandemic points to the fact that migrant labourers were considered mere objects for economic activities in the free market economy.

\section{Dehumanisation of Unskilled Interstate Migrant Labourers During the Pandemic}

Dehumanisation involves treating people as lesser beings. Dehumanisation is often talked about in the context of wars and genocides. However, the two characteristics that mark a dehumanising situation involves taking away from a person, either or both his identity and community (Kelman, 1973). The idea of treating a person as a lesser being need not always involve war-like situations. It need not always be active and violent in nature but could also be indirect exclusion (Oliver, 2011). Indirect deprivations of identity and exclusions from the community are cases of dehumanisation, though it does not involve organised dehumanisation. While the class and caste system often dehumanises the migrant labourers, the pandemic period was even more dehumanising for migrant labourers.

The spraying of migrant labourers with chemical solutions was such a dehumanising incident (BBC, 2020; Aljazeera, 2020; Gupta et al., 2020). Reports surfaced from the state of Uttar Pradesh where migrant labourers were videotaped rushing to collect banans in a transit centre, revealing the plight of the migrant labourers (The Quint, 2020). While the state had been catering to the needs of the middle class and the upper class that are privileged, the migrant labourers were paid no attention to. The migrant labourers faced a serious loss of their individual dignity and a consequent loss of their esteem as an individual, i.e. their identity.

The dehumanisation of migrant labourers was even worse, that sixteen migrant labourers died in Maharashtra as a freight train hit and run the tired migrant labourers who were sleeping on the railway lines during their journey on foot to home (Mahale \& Banarjee, 2020; The Indian Express, 2020). Many others too have lost lives during their ordeal back home. The reports from railway officials suggest another 80 deaths inside the special 'shramik trains' arranged for transporting migrant labourers (Sharma, 2020). Also, migrant labourers on their return to many home states were quarantined in poor facilities with poor sanitation, scarce drinking water and bad food (Jafri, 2020; Loiwal, 2020; Misra, 2020). While other professionals travelling from overseas and within the border had better quarantine 
facilities in their communities, the migrant labourers were discriminated against as an inferior community (The Hindu, 2020). These incidents show how migrant labourers were dehumanised by the pitfalls in the administrative system.

\section{Whose Welfare State?: the Dignity Violated}

Article 23 of the United Nations Universal Declaration of Human Rights (1948) states, 'Everyone who works has the right to just and favourable remuneration ensuring for himself and his family an existence worthy of human dignity, and supplemented, if necessary, by other means of social protection'. The article reiterates the importance of protecting the human dignity of the working class by ensuring social protection in necessary times. The article seeks the member states to ensure measures to avoid violation of human dignity of labourers. The migrant labourers constitute a class that undergo human dignity violations and the pandemic brought to light some of the intense forms of dignity violation of migrant labourers. A welfare state is founded on the principles of equal opportunities, equitable distribution of wealth and a public responsibility towards the marginalised (Encyclopaedia Britannica, n.d.). A welfare state is entitled to promote the social and economic wellbeing of its citizens. The Directive Principles of the State Policy in the Indian Constitution seeks to promote the Welfare of the citizens emphasising on social, economic and political justice (Joshi, 1983). The idea of social, political and economic justice put forth by the constitution involves a call for protecting human dignity. The migrant labourers were denied their dignity through visible patterns of social, economic and political injustice. They were subjected to the violence of dignity in the forms of humiliation, instrumentalisation, degradation and dehumanisation. The cases of extreme human dignity violation during the pandemic were just a manifestation of what lied deep within the society and the system. Migrant labourers are a group of people with their dignity under threat in modern India. It raises the question of the dignity of the marginalised in a so-called welfare state.

\section{Pandemic Response: What Worked and What Needs Revamping}

While this research has been majorly focusing on the violations of human dignity, there were instances of efforts to ensure the welfare of the migrant labourers in many parts of the country. The state of Kerala, for instance, opened relief camps where migrant labourers were provided food and recreational facilities (Nileena, 2020) and the central government rolled out a package to provide free food grains for 8 crore migrant labourers (The Economic Times, 2020).
Non-governmental organisations and charitable organisations played a crucial role in assisting migrant labourers to meet the basic needs by providing shelter, food, healthcare and other basic necessities (Suresh et al., 2020). These measures were all intended at ensuring the welfare of the migrant labourers. However, such efforts mostly revolved around ensuring the basic needs and did not take into consideration the 'rights' or 'dignity' perspective.

A true welfare state demands the protection of the dignity of migrant labourers as equal citizens. The acumen in expatriating citizens stranded in foreign nations showed the efficacy of the system in pooling resources for the welfare of the citizens during the pandemic. The same acumen was necessary in the case of the migrant labourers as well. They are equal citizens and they contribute to the economy and the society as well. The inequalities they face within their homeland raises serious questions of the nature of the welfare state in place. To change the current situation, extensive measures from the state to enforce strict 'human dignity protection' measures should be in place. The state should approach the problem from the perspective of 'dignity' to include the migrant labourers in the mainstream social fabric; an immediate reflection of the same could be initiating social security measures for migrant labourers. The state and society need to transcend the 'needs-based approach' to the problems of migrant labourers and start adopting a 'dignity based approach'.

\section{Conclusion}

The idea of a welfare state is inclusive in itself, but the theory does not often translate into practice. The Indian Union has implemented legislations like The Inter-State Migrant Workmen Act, (1979) aimed at the welfare of migrant labourers. The act, however, is primarily concerned with civil and economic rights. Even the minimum financial and civil protection ensured under the act is often undermined due to belowpar implementation. The second and third-generation human rights that ensure human dignity in an extensive degree are yet to be addressed. The class and caste divide rooted in the social fabric of India precipitates discrimination and consequently a violation of human dignity of the migrant labourers. This basic discriminatory structure of the society has a role in inciting the instances of violations of migrant labourers' human dignity during the pandemic.

While the pandemic was an unforeseen event taking the state off-guard, it cannot be pictured as a justifiable reason to put the dignity and rights of a group of citizens at risk. The pandemic-induced plight was just the culmination of an already complacent system. The report of the working group of migration (Government of India, 2017) set up by the Ministry of Housing and Urban Poverty Alleviation that 
had recommended comprehensive social security measures for migrant workers is still awaiting action. This points to the fact that the state has been complacent in this regard. The visible efficacy in pooling resources to repatriate Indians abroad was a testimony to the capabilities of the state in managing crisis situations. However, this vigorous approach was absent in the case of migrant labourers raising doubts on the state's commitment towards internal migrants. The state needs to initiate a long term plan for the migrant labourers. Given the size of the migrant population of India, a centralised approach is out of the equation (Suresh et al., 2020). A public-private partnership model that decentralises the approach to migrant labourers' welfare is a more suitable alternative. Moreover, migrant labourers' issues must be perceived from a dignity perspective emphasising their rights.

\section{Declarations}

Conflict of Interest The authors declare no competing interests.

\section{References}

Agarwal, A., \& Raj, R. (2020). Migrant workers in India: The pandemic pressure. The London School of Economics and Political Science. https://blogs.lse.ac.uk/socialpolicy/2020/06/18/migrantworkers-in-india-the-pandemic-pressure/

Agoramoorthy, G., \& Hsu, M. J. (2021). How the coronavirus lockdown impacts the impoverished in India. Journal of Racial and Ethnic Health Disparities, 8(1), 1-6. https://doi.org/10.1007/ s40615-020-00905-5

Ameen, F. (2020, May 23). No food and water aboard Shramik Special trains. The Telegraph Online. https://www.telegraphindia.com/india/ coronavirus-no-food-and-water-aboard-shramik-special-trains/cid/ 1775256

Ashok, S., \& Thomas, N. (2014a). A study on issues of inter - state migrant labourers in India. International Journal of Scientific \& Engineering Research., 5(7), 91-94.

Ashok, S., \& Thomas, N. (2014b). A study on issues of inter-state migrant labourers in India. International Journal of Scientific and Engineering Research, 5(7), 91-94.

Aurangabad train accident: 16 migrant workers run over, probe ordered. (2020, May 8). The Indian Express. https://indianexpress. com/article/india/india-lockdown-maharashtra-aurangabad-migrantworkers-killed-train-6399556/

Austin, G. (1999). The Indian Constitution: Cornerstone of a Nation. Oxford University Press.

A question of quarantine: On migrant workers and other travellers. (2020, May 16). The Hindu. https://www.thehindu.com/opinion/ editorial/a-question-of-quarantine-the-hindu-editorial-on-differentrules-for-migrant-workers-and-other-travellers/article31596344.ece

Babu, R., \& Sahay, A. (2020, May 5). 'Let Congress keep the money': Kerala CM refuses party aid for migrants' train fares. The Hindustan Times. https://www.hindustantimes.com/india-news/ let-congress-keep-the-money-kerala-cm-refuses-party-aid-formigrants-train-fares/story-FkUbSN114rSw0yKX6Y4AkK.html

Bakshi, P. M., \& Kashyap, S. C. (1982). The constitution of India. Universal Law Publishing.
Banerjee, B., \& Knight, J. B. (1985). Caste discrimination in the Indian urban labour market. Journal of Development Economics, 17(3), 277-307. https://doi.org/10.1016/0304-3878(85)90094-x

Burton, N. (2014). The psychology of humilation. Psychology Today. https://www.psychologytoday.com/intl/blog/hide-and-seek/ 201408/the-psychology-humiliation

Census. (2011). Office of the Registrar General \& Census Commissioner, Ministry of Home Affairs, Government of India. Retrieved from https://censusindia.gov.in/2011-common/censusdata2011.html

Chander, R., Murugesan, M., Ritish, D., Damodharan, D., Arunachalam, V., Parthasarathy, R., Raj, A., Sharma, M. K., Manjunatha, N., Bada Math, S., \& Kumar, C. N. (2020). Addressing the mental health concerns of migrant workers during the COVID-19 pandemic: An experiential account. International Journal of Social Psychiatry. Advance online publication. https://doi.org/10.1177/0020764020937736

Chaos in UP transit centre as workers try to collect bananas. (2020, May 2). The Quint. https://www.thequint.com/news/india/chaosin-prayagraj-up-transit-centre-as-migrant-workers-collect-banana

Chaturvedi, A. (2020, May 19). 'Cheap politics': Cong slams UP govt after row over buses to ferry migrant workers. The Hindustan Times. https://www.hindustantimes.com/india-news/cheappolitics-congress-slams-up-govt-after-row-over-buses-to-ferrymigrant-workers/story-wjPzbunsfgr7cPa3DMf2mO.html

Choudhari, R. (2020). COVID 19 pandemic: Mental health challenges of internal migrant workers of India. Asian Journal of Psychiatry, 54, 102254. https://doi.org/10.1016/j.ajp.2020.102254

Chowdhury, D. R. (2020, May 17). Coronavirus lockdown: if India treats its migrant workers like dirt, blame it on caste. South China Morning Post. https://www.scmp.com/week-asia/politics/article/3084650/ coronavirus-lockdown-if-india-treats-its-migrant-workers-dirt

Collins, P. H., \& Bilge, S. (2016). Intersectionality. John Wiley \& Sons.

Coronavirus: Anger as migrants sprayed with disinfectant in India. (2020, March 31). BBC. https://www.bbc.com/news/worldasia-india-52093220

Das, M. B., \& Dutta, P. V. (2007). Does caste matter for wages in the Indian labor market. The World Bank.

DDU-GKY-Ministry of Rural Development. (2015). Migration support centre: Reference framework. http://ddugky.gov.in/sites/default/ files/knowledgeBank/Migration_Support_Centre_Reference_ Framework.pdf

Deaths in Shramik special trains cannot be attributed to hunger \& food shortage: Railway board chairman. (2020, May 29). News 18. https://www.news18.com/news/india/deaths-inshramik-special-trains-cannot-be-attributed-to-hunger-foodshortage-railway-board-chairman-2643787.html

De Haan, A. (1997). Unsettled settlers: Migrant workers and industrial capitalism in Calcutta. Modern Asian Studies, 31(4), 919-949. https://doi.org/10.1017/S0026749X00017200

Encyclopaedia Britannica. (n.d). Welfare state. Retrieved from https:// www.britannica.com/topic/welfare-state

FM announces free foodgrains for 8 crore migrant workers for 2 months. (2020, May 14). The Economic Times. https:// economictimes.indiatimes.com/news/economy/policy/fm-announcesfree-foodgrains-for-8-crore-migrant-workers-for-2-months/articleshow/ $75738241 . \mathrm{cms}$ ?from $=\mathrm{mdr}$

Fox, M. (2020, May 16). Don’t spray disinfectants to kill coronavirus, WHO advises. $C N N$. https://edition.cnn.com/world/live-news/coronaviruspandemic-05-16-20-intl/h_0f2325d2b58893ae656ac8e522afad79

Ganguly, S. (2020, June 2). India's coronavirus pandemic shines a light on the curse of caste. The Conversation. https://theconversation.com/indiascoronavirus-pandemic-shines-a-light-on-the-curse-of-caste-139550

Government of India. (2017). Report of the Working Group on Migration. Ministry of Housing and Urban Poverty Alleviation. 
Guha, P., Islam, B., \& Hussain, M. A. (2020). COVID-19 lockdown and penalty of joblessness on income and remittances: A study of inter-state migrant labourers from Assam, India. Journal of Public Affairs, e2470. Advance online publication. https://doi. org/10.1002/pa.2470

Gupta, S., Mitra, E., \& Sud, V. (2020, March 30). Migrant workers sprayed with disinfectant in one Indian state. $C N N$. https://edition. cnn.com/2020/03/30/india/india-migrant-workers-sprayed-intl/ index.html

Hit by lockdown, stranded on roads: Migrant labourers walk for days to reach home. (2020, March 26). India Today. https://www. indiatoday.in/india/story/coronavirus-outbreak-lockdownmigrant-workers-condition-1659868-2020-03-26

Indian migrant workers sprayed with disinfectant chemical. (2020). Al Jazeera. https://www.aljazeera.com/programmes/newsfeed/ 2020/04/indian-migrant-workers-sprayed-disinfectant-chemical200406104936658.html

Inter State Migrant Workmen Act. (1979). Retrieved from https://clc.gov. in/clc/acts-rules/inter-state-migrant-workmen

Ito, T. (2009). Caste discrimination and transaction costs in the labor market: Evidence from rural North India. Journal of Development Economics, 88(2), 292-300. https://doi.org/10.1016/j. jdeveco.2008.06.002

Jafri, A. A. (2020, April 17). No food, water, or even soap: Migrant workers in quarantine desperate to return home. News Click. https:// www.newsclick.in/Uttar-Pradesh-Migrant-Workers-QuarantineConditions-COVID-19

Jane, C. A. (2016). A study on the internal migrant labour - Issues and policies. Indian Journal of Applied Research, 6(4), 81-83.

Joshi, G. N. (1983). The Constitution of India. Delhi: Macmillan India

Kapoor, B. L. (1987). Labour market discrimination against migrant workers in an Indian state: The case of Punjab. Journal of Development Studies, 23(3), 402-417. https://doi.org/10.1080/00220388708422040

Kaufmann, P. (2011). Instrumentalisation: What does it mean to use a person?. In P. Kaufmann., H. Kuch., C. Neuhauser, \& E. Webster (eds.) Humiliation, degradation, dehumanisation: Human dignity violated. (pp. 57-66). Springer.

Kaufmann, P., Kuch, H., Neuhäuser, C., \& Webster, E. (2011). Humiliation, degradation, dehumanisation: Human dignity violated. Springer.

Kelman, H. C. (1973). Violence without moral restraint: Reflections on the dehumanisation of victims and victimisers. Journal of Social Issues, 29(4), 25-61.

Khanna, A. (2020). Impact of migration of labour force due to global COVID-19 pandemic with reference to India. Journal of Health Management, 22(2), 181-191. https://doi.org/10.1177/0972063420935542

Kotzmann, J., \& Seery, C. (2017). Dignity in international human rights law: Potential applicability in relation to international recognition of animal rights. Michigan State International Law Review., 26(1), 1-42.

Kulkarni, C. (2020, May 6). Coronavirus lockdown: Karnataka cancels inter-state trains fearing labour shortage. Deccan Herald. https:// www.deccanherald.com/state/top-karnataka-stories/coronaviruslockdown-karnataka-cancels-inter-state-trains-fearing-labourshortage-834086.html

Kumar, K., Mehra, A., Sahoo, S., Nehra, R., \& Grover, S. (2020). The psychological impact of COVID-19 pandemic and lockdown on the migrant workers: A cross-sectional survey. Asian Journal of Psychiatry, 53, 102252. https://doi.org/10.1016/j.ajp.2020.102252

Lalwani, V. (2020, May 27). 'Is this a joke?': On Shramik trains, passengers complain of long delays - with little food or water. Scroll. in. https://scroll.in/article/962998/is-this-a-joke-on-shramik-trainspassengers-complain-of-long-delays-with-little-food-or-water

Loiwal, M. (2020, April 8). Coronavirus: It's traumatic, say migrant labourers in West Bengal's quarantine facilities. India Today. https://www. indiatoday.in/india/story/coronavirus-outbreak-migrant-labourersquarantine-malda-west-bengal-1664710-2020-04-08

Madheswaran, S., \& Attewell, P. (2007). Caste discrimination in the Indian urban labour market: Evidence from the National Sample Survey. Economic and Political Weekly, 42(41), 4146-4153.

Mahale, A., \& Banarjee, S. (2020, May 8). 16 migrant workers run over by goods train near Aurangabad in Maharashtra. The Hindu. https://www.thehindu.com/news/national/other-states/ 16-migrant-workers-run-over-by-goods-train-near-aurangabadin-maharashtra/article31531352.ece

Misra, R. (2020, May 22). Bad food, water fights, 2 toilets for $240-$ Bihar's migrants come home to a different crisis. The Print. https:// theprint.in/india/bad-food-water-fights-2-toilets-for-240-biharsmigrants-come-home-to-a-different-crisis/426651/

Nath, D. (2020, September 14). Govt. has no data of migrant workers' death, loss of job. The Hindu. https://www.thehindu.com/news/ national/govt-has-no-data-of-migrant-workers-death-loss-of-job/ article32600637.ece

Nileena, M.S. (2020, March 28) 'How the Kerala government is shaping and implementing its COVID-19 response'. The Caravan. https://caravanmagazine.in/health/covid-19-coronaviruskerala-vijayan-shailaja-healthcare-system

Oliver, S. (2011). Dehumanisation: Perceiving the body as (in)human. In In P. Kaufmann., H. Kuch., C. Neuhauser, \& E. Webster (eds.) Humiliation, degradation, dehumanisation: Human dignity violated. (pp. 57-66). Springer.

Migrant labourers leaving Delhi complain of exorbitant ticket prices in packed buses. (2020, May 21). Outlook. https://www.outlookindia. com/website/story/india-news-migrant-labourers-leaving-delhicomplain-of-exorbitant-ticket-prices-in-packed-buses/353204

Migrant labourers return home, only to face 'boycott'. (2020, March 30). The New Indian Express. https://www.newindianexpress.com/nation/2020/ mar/30/they-return-home-only-to-face-boycott-2123241.html

Pandey, S. (2020, April 2). Planes for rich, not even chappals for us - migrants lament as they walk home in UP. The Print. https://theprint.in/india/planes-for-rich-not-even-chappals-forus-migrants-lament-as-they-walk-home-in-up/393217/

Picherit, D. (2019). Labour migration brokerage and Dalit politics in Andhra Pradesh: A Dalit fabric of labour circulation. Journal of Ethnic and Migration Studies, 45(14), 2706-2722. https://doi.org/ 10.1080/1369183X.2018.1528101

Rajagopal, K. (2020, May 26). Supreme Court orders Centre and States to immediately provide transport, food and shelter free of cost to stranded migrant workers. The Hindu. https://www. thehindu.com/news/national/supreme-court-takes-suo-motucognisance-of-migrant-workers-issue/article31679389.ece

Reddy, B., \& Olsen, W. (2012). Adaptation of the rural working class in India: A case study of migrant workers. In D. Clark (Ed.) Adaptation, poverty and development (pp. 181-214). Palgrave Macmillan.

Row over buses for migrants: Uttar Pradesh Congress president, Priyanka Gandhi Vadra's personal secretary booked for 'cheating and forgery'. (2020, May 19). First Post. https://www.firstpost.com/politics/ row-over-buses-for-migrants-uttar-pradesh-congress-presidentpriyanka-gandhi-vadras-personal-secretary-booked-for-cheatingand-forgery-8385211.html

Sensen, O. (2016). Kant on human dignity. De Gruyter.

Shah, A., \& Lerche, J. (2020). Migration and the invisible economies of care: Production, social reproduction and seasonal migrant labour in India. Transactions of the Institute of British Geography, 45(4), 719734. https://doi.org/10.1111/tran.12401

Sharma, M. (2020, May 30). 80 died on Shramik trains for migrants: Railways officials. India Today. https://www.indiatoday.in/india/ story/migrant-workers-shramik-special-trains-80-deaths-16836182020-05-30 
Shramik train run late by $10 \mathrm{hrs,} \mathrm{no} \mathrm{food,} \mathrm{water} \mathrm{facility;} \mathrm{migrants} \mathrm{protest}$ on tracks. (2020, May 23). The Federal. https://thefederal.com/ news/shramik-train-run-late-by-10-hrs-no-food-water-facilitymigrants-protest-on-tracks/

Singh, K. (2020, April 4). Coronavirus outbreak: Ensuring water, hygiene facilities for migrant labourers can safeguard millions stranded during shutdown. Firstpost. https://www.firstpost.com/india/coronavirusoutbreak-ensuring-water-hygiene-facilities-for-migrant-labourers-cansafeguard-millions-stranded-during-shutdown-8228331.html

Srivastava, R. (2019). Emerging dynamics of labour market inequality in India: Migration, informality, segmentation and social discrimination. The Indian Journal of Labour Economics. 62, 147-171. https://doi.org/10.1007/s41027-019-00178-5

Steigleder, K. (2014). Human dignity and social welfare. In M. Duwell, J. Braarvig, R. Brownsword, \& D. Mieth (Eds.), The Cambridge Handbook of Human Dignity: Interdisciplinary Perspectives (pp. 471-476). Cambridge University Press.

Suresh, R., James, J., \& RSj, B. (2020). Migrant workers at crossroads: The COVID-19 pandemic and the migrant experience in India. Social Work in Public Health, 35(7), 633-643.

The Inter-State Migrant Workmen (Regulation of Employment and Conditions of Service) Act. (1979). (India). http://legislative.gov. in/sites/default/files/A1979-30.pdf

Tomlinson, H., \& Chaurasia, M. (2020, April 8). India's new untouchables: The migrant workers barred from their own homes. The
Times. https://www.thetimes.co.uk/article/indias-new-untouchablesthe-migrant-workers-barred-from-their-own-homes-3q0hzxrs7

United Nations. (1948). Universal declaration of human rights. https:// www.un.org/en/universal-declaration-human-rights/

Varma, S. (2020, May 19). Why India's legal and labour system needs to be reconfigured to really help migrant workers. The Wire. https:// thewire.in/labour/india-labour-legal-system-migrant-workers

Wankhede, H. S. (2020, April 5). The coronavirus pandemic has strengthened class segregation in India. The Wire. https://thewire.in/rights/ the-coronavirus-pandemic-and-class-segregations

Webster, E. (2011). Degradation: A human rights law perspective. In P. Kaufmann., H. Kuch., C. Neuhauser, \& E. Webster (Eds.) Humiliation, degradation, dehumanisation: Human dignity violated. (pp. 67-84). Springer.

Without food for days and in searing heat, migrants die on Shramik special trains. (2020, May 27). The Wire. https://thewire. in/labour/without-food-for-days-and-in-searing-heat-migrantsdie-on-shramik-special-trains

Zabeer, S., Inbaraj, L. R., George, C. E., \& Norman, G. (2019). Quality of life among migrant construction workers in Bangalore city: A cross-sectional study. Journal of Family Medicine and Primary Care, 8(2), 437-442. https://doi.org/10.4103/jfmpc.jfmpc_424_18 